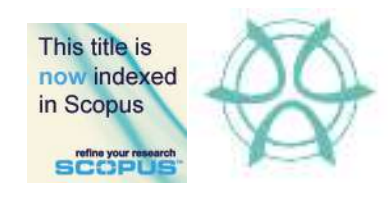

\title{
A FRAMEWORK OF CHALLENGES FACING THE SAFE CITY PROGRAMME IN KUALA LUMPUR
}

\author{
Seng Boon Lim ${ }^{1}$, Yong Chee Kong ${ }^{2}$, Mohd Fadzil Abdul Rashid ${ }^{3}$, \\ Jalaluddin Abdul Malek ${ }^{4}$ \\ ${ }^{1,4}$ School of Social, Development and Environmental Studies \\ Faculty of Social Sciences and Humanities \\ UNIVERSITI KEBANGSAAN MALAYSIA \\ ${ }^{2}$ PLANMalaysia (Federal Department of Town and Country Planning) \\ MINISTRY OF TERRITORIES, MALAYSIA \\ ${ }^{3}$ Department of Town \& Regional Planning, Faculty of Architecture, \\ Planning \& Surveying \\ UNIVERSITI TEKNOLOGI MARA (PERAK BRANCH)
}

\begin{abstract}
The Safe City Programme was launched one and a half-decade ago in Malaysia as one of the National Key Result Areas (NKRAs) strategy to curb crimes. However, the crime rates, in particular in Kuala Lumpur (KL), have shown little evidence of abating. Little is understood of the actual challenges facing the programme. Therefore, questions have been raised and many researchers are attracted to focus on this scenario. Thus, this study aimed to assess local players' views of the challenges facing the safe city programme in KL and to provide a framework for the prevention strategies. The research involved qualitative indepth interviews with key players in the area of safe city, crime experts and officials, and community heads. Themes and a framework were formulated through thematic analysis. The results showed that the understanding of a safe city programme could be differentiated through the lens of sustainability and resilience challenges, as well as their levels of prevention. Thus, the grey area of tertiary prevention strategies could be identified and strengthened.
\end{abstract}

Keyword: Crime-free city, crime prevention, sustainability and resilience challenges, safe cities, urban policy 
Seng Boon Lim, Yong Chee Kong, Mohd Fadzil Abdul Rashid \& Jalaluddin Abdul Malek

A Framework of Challenges Facing the Safe City Programme in Kuala Lumpur

\section{INTRODUCTION}

The Safe City Programme in Malaysia was proposed in early 1998 to the government by the Malaysia Crime Prevention Foundation (MCPF) to minimise the opportunities for crimes and create a safer environment (Ahmad Nazrin et al., 2012). Based on the positive effects of crime prevention as demonstrated through a pilot study conducted in Bangsar Baru, the cabinet had accepted the proposal and launched the Safe City Programme in the year 2004. In 2005, the National Council for Local Government endorsed this programme and instructed all 38 local authorities (city and municipal councils) in Peninsular Malaysia to participate in this programme, including Kuala Lumpur (KL) (Shuhana et al., 2013). In the year 2009, the Safe City Programme was revised and formally listed under the National Key Result Areas (NKRAs) to create awareness on public safety issues related to crime and policing (Yong, 2019). As for KL, the safe city programme and crime prevention through environmental design (CPTED) measures have been integrated and included as one of the development strategies under the city's Draft KL Structure Plan 2020 (Yong, 2019) and continue to be the main concern in preparing the KL Structure Plan 2040. These measures are meant to prevent uneven scenarios, such as crimes and evil behaviours, faced by urban residents.

According to the Royal Malaysia Police (RMP), the crime index rose significantly between 1980 and 2009, where the worst index was recorded in 2007 in which RM2.04 billion was allocated for crime prevention programmes in Malaysia (Shuhana et al., 2013). In between 2010 and 2017, 42.4\% of the total index crimes in Malaysia happened in KL and Selangor (Dass, 2019). As for the reported street crime rates in KL's central business district (CBD) area, snatch theft and total crimes were increasing, while robberies without firearms and gang robberies without firearms cases were maintained at certain levels (Figure 1).

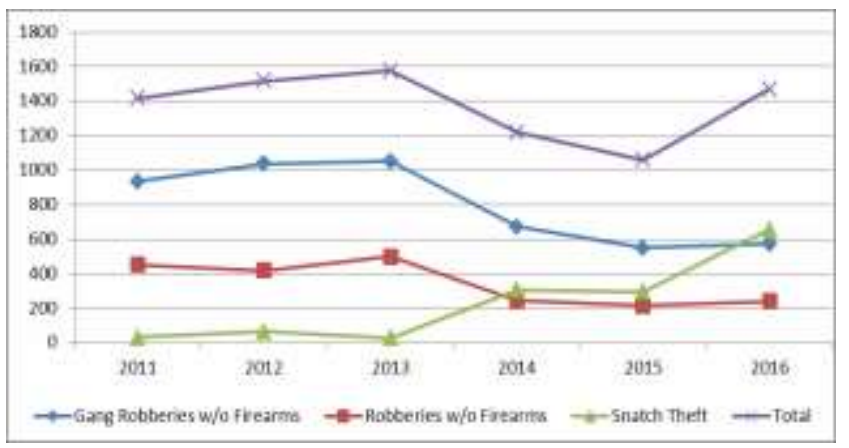

Figure 1: Reported Street Crime in KL's CBD Area Source: RMP (2017) 
PLANNING MALAYSIA

Journal of the Malaysia Institute of Planners (2020)

Based on the above statistics, a question arises as to why despite the ongoing awareness programme on the safe city and the massive amount of budget allocation to fight crimes, challenges are still faced in reducing crimes on the ground. With this curiosity, the current study aimed at understanding the challenges faced by Kuala Lumpur City Hall (KLCH) in conducting the Safe City Programme, and subsequently formulating a structured framework as a tool for managing and synergising the impact of future safe city programmes. To achieve the above objectives, two research questions were formulated in this study, namely, 1) what are the tools for managing and reducing crimes in KL's Safe City Programme? and 2) what are the challenges faced by KLCH in making the safe city programme impactful and in shaping the social well-being of urban residents? The questions were later on turned into interview items so that they could be addressed accordingly.

This paper is structured as follows. The following section discussed the literature related to the relationships of safety, sustainability, and resilience with the urban policy in curbing crimes in Malaysia. Next, the study will elaborate on the qualitative methodology adopted, followed by the findings based on the research questions, discussion, and finally, the conclusion.

\section{LITERATURE REVIEW}

Relationships among the Concept of Safety, Sustainability, and Resilience: To Cast Light on Safe City Challenges

The study observed that most researchers defined the safe city concept as mainly related to "crime-free cities" and also put safety as part of the macro concepts of sustainable and resilient cities. For example, Jalaluddin and Mohd Asruladlyi (2015) and Shuhana et al. (2013) stated that the safe city concept is a micro concept involving the security aspect to achieve macro development in building a sustainable and liveable city. The New Urban Agenda and the call of SDG 11 also stated the aim of making cities "safe, resilient, and sustainable" (UN Habitat, 2017). UN Habitat (2017) shared their vision for a safe city as a city which is suitable for inclusive human settlement and for the people to perform daily activities without the fear of crime and violence. Concerning the sustainability concept, Leach et al. (2010) defined it as "the capability of maintaining over indefinite periods specified qualities of human well-being, social equity, and environmental integrity". Thus, to maintain and surpass the quality of "safety scenarios" of human settlement in crime-free cities, it is imagined as to sustain the intergenerational equity of human's life, transcending from the level of highcrime, medium-crime, low-crime and finally reaching the crime-free status in living, working, and playing. However, as opportunities and problems co-exist in routine human activities in cities, the evil side of likely offenders also co-exist with decent citizens (potential victims) and capable guardians (see Baum, 2011). When criminal acts occur, the injured victims or remorse offenders will still have 
Seng Boon Lim, Yong Chee Kong, Mohd Fadzil Abdul Rashid \& Jalaluddin Abdul Malek

A Framework of Challenges Facing the Safe City Programme in Kuala Lumpur

to face their lives, whether leading a positive livelihood or continuing to indulge in the negative incivility acts.

Therefore, the concept of resilience comes in where society needs to "bounce" back to be able to perform daily activities well without fearing crimes. According to Roostaie et al. (2019), the concept of resilience refers to gaining momentum, having the capacity to persist in the face of change, and practising response to the damage caused. The National Security Strategy of the United States defines resilience as "the ability to adapt to changing conditions and prepare for, withstand, and rapidly recover from disruption" (President of the United States, 2010). Until recently, this resilience concept has gained ground as it has been adopted in the Safe City Index (Economist Intelligence Unit, 2019) and policy documents such as the US national doctrine in 2010. Another study by Achour et al. (2015) reported the Japanese CASBEE ${ }^{\circledR}$ and the German DGNB as the tools in which resilience has been integrated into the sustainability assessment framework. Despite the existing differences among the concepts, Roostaie et al. (2019) formed four types of relationship between sustainability and resilience (refer Figure 2).

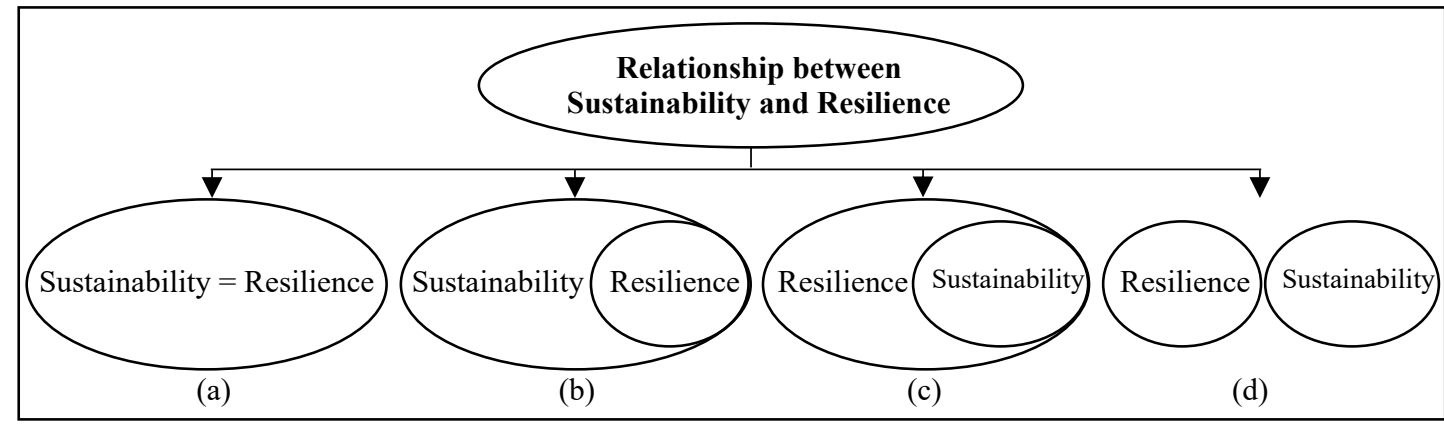

Figure 2: Difference relationships between sustainability and resilience Source: Roostaie et al. (2019)

From the four types of relationship between the concept of sustainability and resilience summarised by Roostaie et al. (2019) and the above examples of assessment tools, the study found that "sustainability" maintains its dominant role as the preferred development paradigm with the concepts of "resilience" and "safety" as components of it (refer Figure 2(b)). The study views these concepts as in ideal states and the scenario in Figure 2(b) could be turned into challenges of action in addressing the safety issue in urban policy planning and development (Davidson et al., 2019).

Urban Policies and Strategies Relevant to Safe City and Crime Prevention in Malaysia 
PLANNING MALAYSIA

Journal of the Malaysia Institute of Planners (2020)

The study observed that there are notable urban development planning policies and strategies related to the safe city and crime prevention in Malaysia. However, the designed strategies and programmes seem to be based on solving ad-hoc scenarios of rising urban crime rates, as well as lacking in understanding of the challenges faced and of introducing a long-term solution to achieve the vision of a crime-free city. Such urban policies and strategies can be traced back to the topdown five-year plans adopted by Malaysia. For example, the Fifth Malaysia Plan (1986-1990) incorporated measures to foster and maintain a close relationship between the police and the public in fighting crimes. Systems such as the "Community Constable" (KONMAS) were introduced in selected areas in Georgetown, Ipoh, Johor Bahru, and Petaling Jaya. In the Sixth Malaysia Plan (1991-1995), the "Rakan Muda Programme" was introduced for youth development and to prevent them from unhealthy activities and crime. Consequently, the Seventh and Eighth Malaysia Plans (1996-2000 and 20012005, respectively) introduced the Caring Community and Neighborhood Committee expansively to promote good neighbourliness in helping to reduce the crime rates in residential areas.

Another important programme that emphasises the social aspect is the National Social Service Programme, which was also introduced during the Eighth Malaysia Plan period. The programme was aimed at promoting a spirit of cooperation and partnership among government agencies, private and nongovernmental organisations (NGOs), and other volunteer bodies to help combat crimes (Nor Eeda, 2006). In ensuring continuity, the Ninth Malaysia Plan (20062010) introduced the Lifelong Learning Programme and Centre of Unity to form community patrolling and knowledgeable organising committees in preventing crimes (Nor Eeda, 2006). To continue to bring prosperity and safety to the nation, the Tenth and Eleventh Malaysia Plans (2011-2015 and 2016-2020, respectively) included three key strategies to enhance safety in the country. One of the strategies is to reduce the crime rate (overall index crime rate), especially street crime via public concern and awareness (Yong, 2019).

The National Physical Plan 3rd Edition (2016) also incorporated the safety aspect to sustain national growth. Thrust-3, which mentioned "building inclusive and liveable communities - creating a safe environment as one of its strategic directions" was timely. Before that, the Fifth Thrust in the First National Urbanisation Policy, which addressed "the realisation of a prosperous urban living environment" also highlighted the importance of promoting safety aspects in city planning and development (FDTCP, 2006).

Presently, as mentioned earlier, the CPTED strategies are the main actions being integrated into safe city programmes both locally and nationally. This approach needs to be materialised at community and local authority levels. Most of the key elements of the CPTED are based on the opportunity theories such as the Routine Activities Theory (Cohen \& Felson, 1979) and Broken 
Seng Boon Lim, Yong Chee Kong, Mohd Fadzil Abdul Rashid \& Jalaluddin Abdul Malek

A Framework of Challenges Facing the Safe City Programme in Kuala Lumpur

Window Theory (Wilson \& Kelling, 1982) in creating environmentally safer urban environments.

At the local authority level, the KLCH touched on the Safe City Programme from the physical planning perspective. Further, the KLCH provided more details by introducing policies of Urban Design (UD 23) and Communities Facilities (CF 18) (KLCH, 2004). UD 23 states that KLCH shall draw up an urban design framework together with a comprehensive set of urban design guidelines to ensure public safety and health, and designate a body responsible for implementation and coordination with other relevant authorities and policy. Meanwhile, policy CF 18 states that $\mathrm{KLCH}$ shall, in consultation with the appropriate authorities, ensure that sufficient police stations, police posts, and neighbourhood watch centres are provided and adequately distributed. These programmes will be revisited during their implementation stages to determine their effectiveness and to understand the challenges and future intervention strategies to be implemented.

\section{METHODOLOGY}

As stated in the Introduction section, this study applied a qualitative approach to deal with the designed research questions and subsequently synthesised the challenges faced by safe city programmes in Malaysia, in particular, by the $\mathrm{KLCH}$. It includes, first, in-depth interviews with the key players which were identified through purposive and snowball sampling techniques (see Creswell \& Poth, 2018). The interview sessions involved informants that possess the knowledge and background information related to the safe city programme in KL. All of them were recommended by other informants interviewed in the study. In total, nine informants were selected from diverse backgrounds, such as government officials, police, NGOs, and local community heads (Table 1). The study found that these nine informants provided enough data saturation to answer the research questions due to the diversify of their background, which provided multi-perspective answers, thus enriching the finding dimensions.

Table 1: Numbers of informants

\begin{tabular}{lc}
\hline Informant & Quantity \\
\hline Federal and local government officials $(\mathrm{G})$ & 2 \\
\hline Police $(\mathrm{P})$ & 3 \\
\hline NGO representatives $(\mathrm{N})$ & 2 \\
\hline Local community head/safe city programme partners $(\mathrm{C})$ & 2 \\
\hline Total & 9 \\
\hline
\end{tabular}

Thematic analysis through Atlas.ti was applied in this study. Using this analysis, the study looked for similarities and differences, or plausible and spurious data, as well as classifying them into axial coding that consists of categories and themes (Creswell \& Poth, 2018). Then, a constant comparative 
PLANNING MALAYSIA

Journal of the Malaysia Institute of Planners (2020)

method was applied to create the coding scheme. The emergent network of themes was then presented as the final and most important output to help the study identify any relationships or patterns in the data (refer to Figures 3 and 4).

\section{FINDINGS}

This section discusses the analysis of results from the interviews and reports the summary of critical findings according to the research questions.

\section{Tools for Reducing Crimes in KL Safe City Programme}

In its inaugural year of fighting crimes, the government official informant G1 mentioned that the top-down Reducing Crime NKRA framework had introduced programmes such as identifying crime hotspots, strategic deployment of police in these hotspots, and implementing the Omnipresence Programme. As for measures related to the CPTED, many strategies have been launched including installing close-circuit television (CCTV) cameras in high-risk areas and in areas prone to snatch thefts. All the informants concurred that alarms and surveillance cameras are useful. When thieves are aware that their criminal activities will be captured on camera, they might think twice about committing a crime. Similarly, safety mirrors are a great source of security solution. Safety mirrors are effective in ensuring pedestrians' safety, especially at secluded spots and crime hot spot areas. Besides, street lights are also effective. The police informant P1 and government official informant G1 mentioned that KLCH and police recently changed the voltage of all the street lights. Many related agencies such as the FDTCP viewed the programme as successful and it is growing to shape urban prosperity and a secure living environment. "Our streets are no longer dark, and the perception is city centre is a much safer place for public now, " mentioned the community head $\mathrm{C} 2$. Figure 3 provides a summary of the critical findings for Research Question 1.

As far as $\mathrm{KLCH}$ is concerned, the government official G2 pointed out that mixed-use zoning appears to cut down the crime rates. A city centre with lunch counters, offices, condos, and nightlife activities is likely to have more "eyes on the street" at more frequencies in a day. This collective surveillance ostensibly deters criminals. It also makes sense that people would feel a greater sense of ownership and security and care for the city centre where they live, shop, or go to work. Informant G2 suggested that the relevant agencies should consider zoning laws as the current one largely overlooks this tool for crime prevention. More often, when police think about the environmental design for crime prevention, they focus on interventions like sidewalk cameras, street lighting, or new cul-de-sacs. G2 suggested that they should also look at the level of land use alongside urban planners.

In addition, informant $\mathrm{G} 2$ revealed that $\mathrm{KLCH}$ has started exploring how urban nature affects crime. They have reassessed the policies about cleaning 
Seng Boon Lim, Yong Chee Kong, Mohd Fadzil Abdul Rashid \& Jalaluddin Abdul Malek

A Framework of Challenges Facing the Safe City Programme in Kuala Lumpur

and greening vacant lots, as well as developing parks with green installations. This is consistent with the notion by Jane Jacobs (1961) regarding "eyes on the street", well-kept lawns, and community plots that encourage more people to spend time outside in those spaces, leading to a greater degree of informal surveillance of the area and deterring crimes. Beyond the ecological and aesthetic benefits, these investments create a safer environment for the people who work and live nearby.

\begin{tabular}{|c|c|c|c|c|c|}
\hline & \multicolumn{4}{|c|}{ Tools for reducing crimes in KL Safe City Programme } & \\
\hline & $\nabla$ & $\checkmark$ & & $\nabla$ & \\
\hline \multicolumn{2}{|c|}{ Top-down policy } & \multicolumn{2}{|c|}{ Local legitimation } & \multicolumn{2}{|c|}{$\begin{array}{c}\text { Stakeholders \& } \\
\text { collaboration }\end{array}$} \\
\hline $\begin{array}{c}\text { NKRA framework } \\
\text { / CPTED }\end{array}$ & $\begin{array}{l}\text { Mixed-use } \\
\text { zoning }\end{array}$ & $\begin{array}{l}\text { Urban nature } \\
\text { affects crime }\end{array}$ & $\begin{array}{l}\text { Street } \\
\text { raids }\end{array}$ & $\begin{array}{l}\text { Police's active } \\
\text { role }\end{array}$ & $\begin{array}{l}\text { Society's } \\
\text { role }\end{array}$ \\
\hline $\begin{array}{l}\text { Identifying crime } \\
\text { hotspots, strategic } \\
\text { deployment of } \\
\text { police into these } \\
\text { hotspots, and }\end{array}$ & \multirow{3}{*}{$\begin{array}{c}\text { More 'eyes on } \\
\text { the street' at } \\
\text { more times of } \\
\text { day }\end{array}$} & \multirow{2}{*}{$\begin{array}{l}\text { Reassess policies } \\
\text { about cleaning } \\
\text { and greening } \\
\text { vacant lots, } \\
\text { developing parks } \\
\text { with green } \\
\text { installations }\end{array}$} & \multirow{2}{*}{$\begin{array}{l}\text { A long- } \\
\text { term effort } \\
\text { to round up } \\
\text { the } \\
\text { homeless/ } \\
\text { street } \\
\text { dwellers }\end{array}$} & $\begin{array}{l}\text { Police advise } \\
\text { public on } \\
\text { carrying } \\
\text { personal safety } \\
\text { device }\end{array}$ & \multirow[t]{3}{*}{$\begin{array}{c}\text { Communit } \\
\text { y to report } \\
\text { and } \\
\text { participate } \\
\text { actively }\end{array}$} \\
\hline $\begin{array}{l}\text { implementing the } \\
\text { Omnipresence } \\
\text { Program. }\end{array}$ & & & & $\begin{array}{c}\text { More placement } \\
\text { of mobile police } \\
\text { stations }\end{array}$ & \\
\hline $\begin{array}{l}\text { CPTED measures } \\
\text { include installing } \\
\text { CCTV cameras in } \\
\text { high-risk areas, } \\
\text { safety mirrors, and } \\
\text { street lighting. }\end{array}$ & & $\begin{array}{l}\text { Investments in } \\
\text { green and clean } \\
\text { spaces create a } \\
\text { safer } \\
\text { environment }\end{array}$ & & $\begin{array}{c}\text { Safe City } \\
\text { Monitoring } \\
\text { System through } \\
\text { GIS crime } \\
\text { mapping }\end{array}$ & \\
\hline
\end{tabular}

Figure 3: Network of themes on tools for reducing crimes in KL Safe City Programme

The community head informant $\mathrm{C} 1$ noticed that street raids conducted by KLCH are part of the efforts to round up the homeless as the council hopes to clean up the city. Besides, the police informant P1 encouraged the public to play their roles in preventing street crimes. P1 added that the police advised the public to carry a personal safety device like a flashlight (Maglite) when one goes out at night. Government efforts such as the introduction of mobile police stations at certain hotspots have helped much in crime prevention. The police station at Berjaya Times Square (Imbi Street) is one of the examples. Informant P1 added that the placement of mobile stations and patrols by patrol vehicles and the motorcycle patrol unit in focused areas such as Ampang Street and Bukit Bintang area have been effective in reducing the crime index. Meanwhile, the NGO 
informant $\mathrm{N} 1$ hoped that the police could increase patrolling or station more men at snatch theft hot spots.

Collaboration is a key initiative in preventing crimes. In preventing street crimes, all the informants concurred that the agencies responsible for security could not work in a silo. Inward-looking mindset and resistance to sharing information and resources with other people or departments within the organisation must be avoided. Other departments and related agencies have to work closely with the police. When an accident or incident occurs, effective and accurate response and reaction to the accident or incident should be made possible. Also, the government official informant G2 revealed that municipal surveillance demands a non-intrusive security solution and at the same time must address the diverse range of sensitivities, routines, and systems used by various emergency services.

The Safe City Monitoring System (SCMS) is an award-winning project collaboration between the police and FDTCP which can identify crime displacement and potential crime hot spots. This system was highly promoted by the government official informants G1 and G2 during the interview session. The objectives of developing the SCMS are to improve crime data sharing among the crime prevention agencies and to monitor the effectiveness of crime prevention programmes through the provision of Geographic Information System (GIS) crime mapping facilities to the police and local authorities.

Other critical success elements are public awareness and community engagement. The police informant P1 mentioned that safe cities are built through small and scalable initiatives, and people are the critical success factors in building safe cities. Safe cities imply smart citizens. Furthermore, as the public becomes more connected with smartphones and broadband access, more information reaches law enforcement agencies from the public and the public's expectations for governmental services and safety increase accordingly.

\section{Challenges Facing the Safe City Programme in KL}

Concerning the challenges facing the safe city programme in KL, the government official informant G2 informed that previously, most of the projects were funded by the federal government through the Ministry of Home Affairs. The FDTCP as the project manager monitored the spending and budget distribution to the local authority. However, due to the new top-down policy direction of Shared Prosperity Vision 2030 (adjusted from Vision 2020), this safe city programme has been pending for further action and is under the "budget review" status. The NGO informant $\mathrm{N} 2$ and community head informants $\mathrm{C} 1$ and $\mathrm{C} 2$ pointed out that the government's seriousness in preventing crime by allocating appropriate budgets is crucial. Data from (FDTCP, n.d.) showed that the budget allocation for safe city programme in Malaysia was decreasing from RM4.2 billion in the year 2013 to RM10 million in the year 2019. Without sufficient budgets, the 
Seng Boon Lim, Yong Chee Kong, Mohd Fadzil Abdul Rashid \& Jalaluddin Abdul Malek

A Framework of Challenges Facing the Safe City Programme in Kuala Lumpur

existing CPTED facilities could hardly be maintained and improved, and new strategies that are to be implemented at the ground level might be abandoned. Hence, there will be ambiguities and uncertainties due to the failure or delay in implementing the plans (see Matland, 1995).

As for the role of the police, the informant $\mathrm{C} 1$ wished the police would act fast if a crime happens, have a closer appearance to the public, would build public confidence, and also would deter criminals from committing crimes. When this information was conveyed to the police informants P1 and P2, they defended that the police have worked hard in performing their duties, and sometimes the lack of staff is unavoidable. Nevertheless, they agreed that the police act as the main "guardians" in protecting the residents. They also pointed out that the police have set up mobile kiosks in the CBD area and are doing frequent foot-patrolling. Moreover, the police informants mentioned that they face the hurdle of inadequate crime information being provided by the public, as many residents are afraid to interfere with the potential offenders and related gangsters or kongsi gelap. The NGO informant N1 informed that the public is inclined to think that the police have the highest responsibility in reducing crimes, and they tend to criticise rather than helping (see Figure 4).

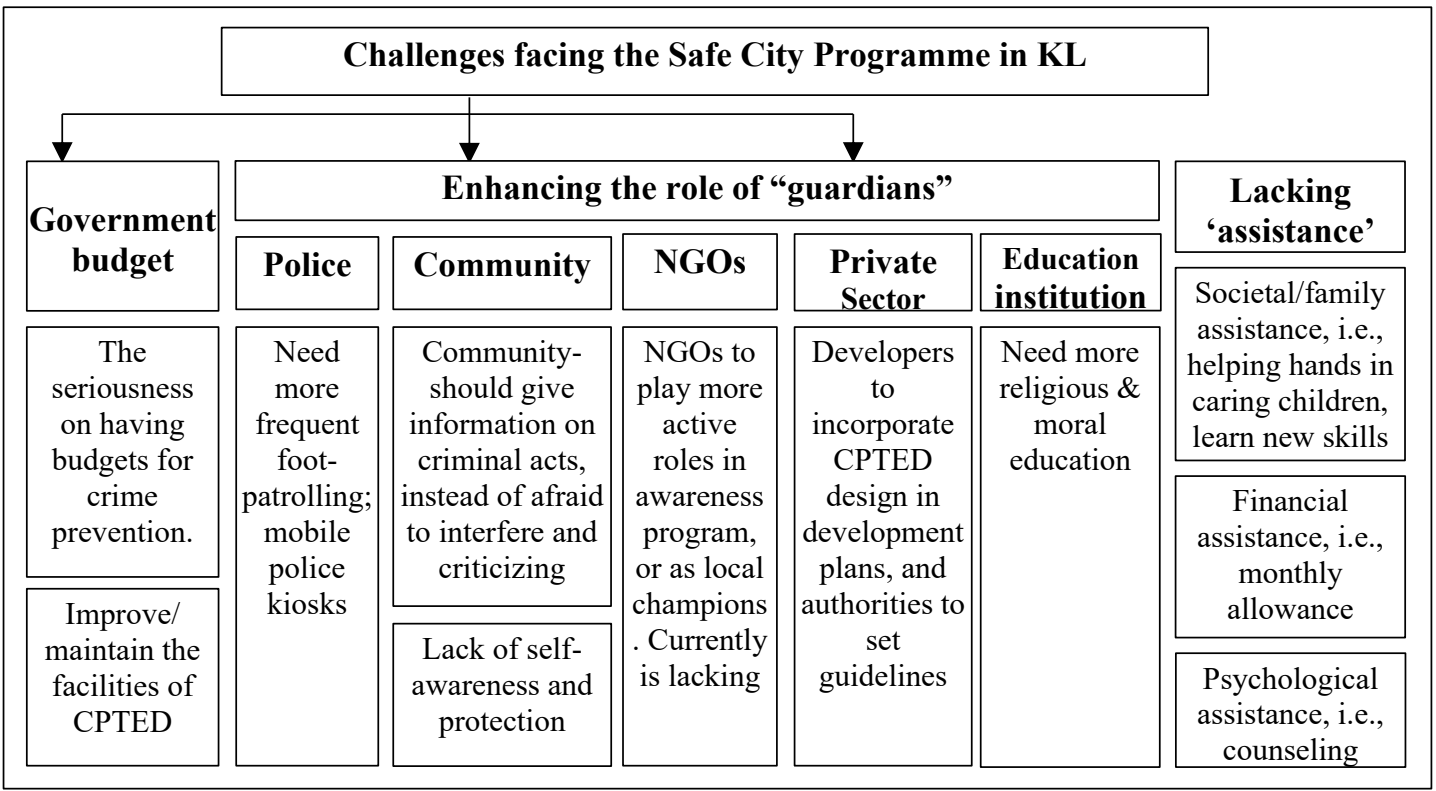

Figure 4: Network of themes on the challenges facing the Safe City Programme in KL

The police informant P3 is concerned about the need for community training on self-awareness and protection, and highlighted that awareness is the key for self-protection. P3 advised that the public, especially pedestrians, should 
PLANNING MALAYSIA

Journal of the Malaysia Institute of Planners (2020)

always look around, avoid stepping out while talking on the phone and never allow criminals to strike by not wearing valuables when they are in secluded areas. The public should discard the mentality that such crimes "are never going to happen to me". Instead, they should take proactive measures to ensure their safety. Senior citizens and women, particularly, must be "street smart" and always alert when walking alone. People should ride bikes on the street instead of on the sidewalk. Thus, pedestrians are advised to get inside a building and wait until the motorists or riders have passed if they see motorists or riders on the sidewalk. The informant P3 added that they must also know the latest tactics employed by snatch thieves, including asking for directions before grabbing the victim's bag or other valuables.

According to the NGO informants $\mathrm{N} 1$ and N2, the MCPF has periodically organised crime awareness events the public and town hall sessions with the police besides encouraging the setting up of crime prevention clubs in secondary schools. However, N1 felt that in practice, not many NGOs have followed the footsteps of Komuniti Polis Malaysia (CAP) and Safer Malaysia in organising crime prevention activities. Hence, the informant urged more NGOs to play more active roles as local safety champions. N2 added that currently, the crime prevention efforts by NGOs are lacking.

Meanwhile, the government official G1 pointed out the challenges faced by the private sector in helping to curb crimes. For example, in applying for planning permission for the development plan, property developers should try to incorporate the CPTED design. However, not many property developers take this crime prevention step into serious consideration. Thus, the informant suggested that the local governments should impose stringent guidelines in ensuring full implementation of the CPTED design on the ground. G1 added that besides the private sector, education institutions should play their role by increasing the number and scope of religious and moral education classes to enhance awareness among children and graduates. The community head informant $\mathrm{C} 2$ concurred that children should receive adequate education in crime knowledge, observe good moral behaviour, and refrain from committing crimes, which will help in curbing the vicious cycle of them being turned into criminals in the future.

Apart from the government and the "guardian" roles discussed above, another challenge faced in the implementation of the Safe City Programme is the lack of "assistance". The NGO informant N2 mentioned that after the occurrence of a crime, three types of assistance are usually needed by the victims, family members of the victims, and the offenders. These three types of assistance are family, financial, and psychological assistance. For family assistance, the offenders' family could be in helpless situations when the breadwinner has been arrested by the police and jailed, or the victims are hospitalised or even died during the criminal acts. In such difficult scenarios where family and childcare 
Seng Boon Lim, Yong Chee Kong, Mohd Fadzil Abdul Rashid \& Jalaluddin Abdul Malek

A Framework of Challenges Facing the Safe City Programme in Kuala Lumpur

assistance are lacking, government departments, community, and society need to assist the family members, for example by providing free childcare or teaching new skills to the ladies so that they can earn a living. Secondly, financial assistance is related to family assistance, and it refers to the monetary assistance provided to the family of victims and offenders. Thirdly and most crucial is the lack of psychological assistance such as counselling services to the victims and offenders. For the former, consistent counselling helps the victims to get out and heal from the fear of crime. For the later, counselling helps the offenders, who are mostly in prison, to feel remorse about their incivility behaviour and the harm that they inflicted. This assistance will help in reducing the cycle of crime in the future. The police informant P1 admitted that not all the criminals are "bad guys", and most of them need better psychological guidance which is currently lacking in society.

\section{DISCUSSION}

From the above findings, the study found that in the security landscape, the street crimes in KL's CBD area are generally at acceptable levels and the police are confident in curbing street crimes. However, there is still some uncertainty in public confidence. These findings reflect the crime statistics shown in Figure 1 where crimes still exist in society, and long-term and consistent efforts are needed to curb these incivility acts. The implementation of the safe city programme in KL's CBD has taken place for 15 years, and it has been generally acknowledged as a good move by the government in curbing crimes. However, the inevitable urbanization trend in KL has caused increasing crime rates. Hence, the CPTED strategies and the utilisation of technology, infrastructure, personnel, and processes need to be monitored and improved from time to time.

For the first research question regarding the tools for reducing crime, three main areas were derived from the interview themes, namely top-down policy, local legitimation, and stakeholders' collaboration (Figure 3). Besides the NKRAs framework and urban policies mentioned in the literature review, insights such as rethinking crime from the perspective of mixed-use zoning and urban nature are good points for curbing crimes as the long-term measures. Urban planners in this context play an important role in guarding the new development plan approvals, such as by applying strict rules in CPTED design checking as well as balanced zoning of residential, commercial, or industrial development and traffic flow to improve the "public eyes" in each zone.

For the second research question regarding the challenges faced by the safe city programme in KL, the study found from the interviews that three factors are crucial, namely the government's budget, enhancing the role of the "guardians" (i.e., the police, community, NGOs, private sector, and educational institutions), and assistance in family, financial, and psychological aspects 
(Figure 4). The challenges faced by the safe city programme necessitates collaboration and responsibility by all the stakeholders.

The study argues that the safe city programme should be carried on not only in KL but also in other urban areas in Malaysia, as its framework is proven to be capable of preventing crime. As discussed in the literature review section earlier, under the bigger scope, the safety issue is always an essential element under the macroscope of sustainable and resilient city planning. Thus, the study attempted to form a framework of the challenges faced, which is presented in Figure 5.

\begin{tabular}{|c|c|c|c|}
\hline \multirow{5}{*}{$\begin{array}{r}\text { In support of } \\
\text { existing } \\
\text { tools: } \\
\text { Top-down } \\
\text { policy, } \\
\text { Local } \\
\text { legitimation, } \\
\& \\
\text { Stakeholders' } \\
\text { collaboration }\end{array}$} & Sustainability Challenge & $\underline{\text { Level of Prevention }}$ & Examples of strategy \\
\hline & Crin & $\begin{array}{l}\text { 3) Tertiary prevention } \\
\text { (assist victims/criminals } \\
\text { from preventing the } \\
\text { repeated crimes) }\end{array}$ & $\begin{array}{l}\text { Psychological assistance, 1.e., } \\
\text { counseling, } \\
\text { Financial assistance, i.e., monthly } \\
\text { allowance, and } \\
\text { Family assistance, i.e., helping hands } \\
\text { in caring children, learn new skills. }\end{array}$ \\
\hline & כ) & $\begin{array}{l}\text { 2) Secondary prevention } \\
\text { (early recognition of } \\
\text { potential offenders) }\end{array}$ & $\begin{array}{l}\text { Promote social development CSPD } \\
\text { activities, care and act fast to deter } \\
\text { 'broken windows', and } \\
\text { Improve/maintain the facilities of } \\
\text { CPTED. }\end{array}$ \\
\hline & & $\begin{array}{l}\text { 1) Primary prevention } \\
\text { (avoid the roots of evil) }\end{array}$ & $\begin{array}{l}\text { Enhance the role of 'guardians', and } \\
\text { Maintain the government's budget }\end{array}$ \\
\hline & S & e & $\begin{array}{l}\text { e, adaptation to risk } \\
\text { epresents desired direction }\end{array}$ \\
\hline
\end{tabular}

Figure 5: The framework of challenges facing the Safe City Programme in Malaysia

Based on the utopian safe city imagination, the existing city could be divided into a high-crime rate, medium-crime rate, low-crime rate, and utopian state of a crime-free city. In applying the safe city programme to achieve such conditions, the "sustainability" paradigm serves as the background challenge and "resilience" as the inner strength of "turning" and adaptation to risk (such as criminal acts). These "bounce back" ability challenges could be further detailed into three levels of crime prevention, namely primary, secondary, and tertiary levels (see Dobovšek, 2009). The primary and secondary levels of prevention are referred to as avoiding the roots of evil and early recognition of potential offenders. Insights from the informants showed that these two levels are implemented at acceptable levels. However, the gaps and most pressing challenges being faced now are on the tertiary level of prevention namely providing family, financial, and psychological counselling assistance, which is to 
Seng Boon Lim, Yong Chee Kong, Mohd Fadzil Abdul Rashid \& Jalaluddin Abdul Malek

A Framework of Challenges Facing the Safe City Programme in Kuala Lumpur

assist victims or criminals in preventing them from repeating their crimes in the future. Examples of the challenges turned strategies are drawn from the interview codes. With such synthesis in the minds of all the stakeholders, the challenges faced by the safe city programme will be put in a better perspective, thus making it easier to be improved.

\section{CONCLUSION}

This paper has contributed to assess the local players' views and the development of a framework on the challenges facing the safe city programme in KL. This developed framework provides an overview of the safe city tools, imagination, challenges, and levels of prevention. It may be applied in other urban areas in Malaysia. This is considered as a new insight for all the stakeholders to comprehend and practice. However, this study has some limitations. The informants' views are subjective and could be biased; thus, further quantitative studies are recommended to test the syntheses formed in this study. Finally, the lesson learnt from this study is that the assistance in family, financial, and psychological aspects of victims or criminals should be strengthened in ensuring the sustainability and resiliency of the safe city programmes.

\section{ACKNOWLEDGEMENT}

This paper did not receive any specific grant from funding agencies in public, commercial, or not-for-profit sectors.

\section{REFERENCES}

Achour, N., Pantzartzis, E., Pascale, F., \& Price, A. D. F. (2015). Integration of resilience and sustainability: From theory to application. International Journal of Disaster Resilience in the Built Environment, 6(3), 347-362.

Ahmad Nazrin, A. A., Siti Noorbaizura, B., \& Noor Azah, A. (2012). The effectiveness of safe city programme as safety basic in tourism industry: Case study in Putrajaya. Procedia - Social and Behavioral Sciences, 42, 477-485.

Baum, H. (2011). Planning and the problem of evil. Planning Theory, 10(2), 103-123.

Cohen, L. E., \& Felson, M. (1979). Social change and crime rate trends: A routine activity approach. American Sociological Review, 44, 588-608.

Creswell, J. W., \& Poth, C. N. (2018). Qualitative Inquiry and Research Design (4th ed.). Thousand Oaks, CA: Sage.

Dass, R. A. S. (2019). Crime trends and patterns in Malaysia. Kyoto Review of Southeast Asia, 25(Trendsletters). https://kyotoreview.org/trendsetters/crime-trends-andpatterns-in-malaysia/

Davidson, K., Nguyen, T. M. P., Beilin, R., \& Briggs, J. (2019). The emerging addition of resilience as a component of sustainability in urban policy. Cities, 92, 1-9.

Dobovšek, B. (2009). Prevention of corruption in practice - Integrity plans. In G. Meško \& H. Kury (Eds.), Crime Policy, Crime Control and Crime Prevention - Slovenian Perspectives (pp. 253-282). Ljubljana: Tipografija Publishing. 
Economist Intelligence Unit (EIU). (2019). Safe Cities Index 2019. London: The Economist, Intelligent Unit.

Federal Department of Town and Country Planning (FDTCP). (n.d.). Program Bandar Selamat (PBS). Retrieved February 1, 2020, from https://www.townplan.gov.my/index.php/en/agensi/program-bandar-selamat

Federal Department of Town and Country Planning (FDTCP). (2006). Dasar Perbandaran Negara. Putrajaya: Ministry of Housing and Local Government Malaysia.

Jacobs, J. (1961). The Death and Life of Great American Cities. New York: Random House.

Jalaluddin, A. M., \& Mohd Asruladlyi, I. (2015). Bandar selamat dan keselamatan komuniti bandar selamat. E-Bangi, 10(1), 97-117.

Kuala Lumpur City Hall (KLCH). (2004). Kuala Lumpur Structure Plan 2020. Kuala Lumpur: Kuala Lumpur City Hall.

Leach, M., Stirling, A. C., \& Scoones, I. (2010). Dynamic Sustainabilities: Technology, Environment, Social Justice. London: Routledge.

Matland, R. E. (1995). Synthesizing the implementation literature: The ambiguityconflict model of policy implementation. Journal of Public Administration Research and Theory, 5(2), 145-174.

Nor Eeda, A. (2006). Pembangunan Komuniti Dalam Pelaksanaan Konsep Bandar Selamat. Msc thesis, Universiti Teknologi Malaysia.

President of the United States. (2010). National Security Strategy. Washington: The White House.

Roostaie, S., Nawari, N., \& Kibert, C. J. (2019). Sustainability and resilience: A review of definitions, relationships, and their integration into a combined building assessment framework. Building and Environment, 154, 132-144.

Royal Malaysia Police (RMP). (2017). Safe City Monitoring System (SCMS). Retrieved June 21, 2017, from the confidential online GIS crime-based data, Royal Malaysia Police.

Shuhana, S., Natasha Azim, H., \& Nur Rasyiqah, A. H. (2013). Implementation of Safe City Program for a liveable city: The case of Kuala Lumpur. 3rd International Conference on Universal Design in the Built Environment, Putrajaya, 11th - 12th November, 355-373.

UN Habitat. (2017). New Urban Agenda. Quito: United Nations Habitat III.

Wilson, J. Q., \& Kelling, G. (1982). Broken windows: The police and neighborhood safety. Atlantic Monthly, 249, 29-38.

Yong, C. K. (2019). The effectiveness of Safe City Program in reducing street crime and fear of crime from the perspective of pedestrian: Case study Kuala Lumpur. PhD thesis, Infrastructure University Kuala Lumpur.

Received: $15^{\text {th }}$ May 2020. Accepted: $1^{\text {st }}$ Sept 2020 